\title{
Examining the Effect of the Secondary Flow-Field on Polymer Electrolyte Fuel Cells Using X-ray Computed Radiography and Computational Modelling
}

Nivedita Kulkarni ${ }^{1}$, Quentin Meyer ${ }^{1}$, Jennifer Hack ${ }^{1}$, Rhodri Jervis ${ }^{1}$, Francesco lacoviello ${ }^{1}$, Krisztian Ronaszegi ${ }^{1}$, Paul Adcock ${ }^{2}$, Paul R. Shearing ${ }^{1}$, Dan J. L. Brett ${ }^{* 1}$

${ }^{1}$ Electrochemical Innovation Lab, Department of Chemical Engineering, UCL, London, WC1E 7JE, United Kingdom.

2Intelligent Energy, Charnwood Building Holywell Park, Ashby Road, Loughborough Leicestershire, LE11 3GB, United Kingdom.

* Author to whom correspondence should be addressed

Tel.: $+44(0) 2076793310$

Web: www.ucl.ac.uk/electrochemical-innovation-lab

Email: d.brett@ucl.ac.uk 


\begin{abstract}
Flow-fields are key factors in determining the operation of fuel cells. While extensive work has been conducted to develop and optimise the reactant flow and current collection performance of polymer electrolyte membrane fuel cell (PEMFC) components, there is a factor that remains largely unaccounted for. Depending on how a membrane electrode assembly (MEA) is incorporated into a cell, there will often be a small gap between the edge of the gas diffusion layer (GDL) and the seal or bipolar plate. This gap acts as a 'secondary flow-field' (SFF) that can bypass or affect/augment the conventional or 'primary flow-field'. Understanding how this affects performance (either positively or adversely) is essential for holistic flow-field design. This paper describes the issues associated with the SFF, examines how cell compression affects its width due to lateral expansion of the GDL and discusses the results of a 3-D computational model that investigates the effect of the SFF during dead-ended anode (DEA) operation for a fuel cell without a macroscopic (conventional) anode flowfield.
\end{abstract}

Keywords: Secondary flow-field; Manufacturing tolerance; Gas diffusion layer compression; Computational modelling; X-ray radiography.

\title{
Highlights
}

- The gap around GDL and seal represents a secondary flow-field.

- Effect of GDL compression on its lateral expansion quantified.

- Secondary flow-field improves dead-ended operation. 


\section{Introduction}

Polymer electrolyte membrane fuel cells (PEMFCs) offer clean energy generation for a range of applications, including the stationary and automotive sectors [1,2]. Fuel cell behaviour is largely determined by its components, the design of the flow-fields being particularly important [3-6], with extensive research having been performed to improve flow and current collection characteristics [710].

\subsection{Existence of secondary flow-field in the operating fuel cell}

The key functions of the flow-field are to deliver an even distribution of reactant species over the active area of the electrode and removal of the by-products, while ensuring good current collection [11-13]. Flow-fields vary in shape, dimensions, orientation and configuration $[1,3]$. The majority of PEMFCs depend on the conventional flow-field for reactant distribution; although some fuel cell designs dispense with a conventional primary flow-field and rely on the lateral flow of reactant through the GDL [14-19].

Accurate and reproducible cell/stack assembly is key to ensuring good performance and durability. Depending on the tolerance of the manufacturing processes and the components used, integration of a membrane electrode assembly (MEA) into a cell can lead to a narrow gap between the GDL and the gasket/sealing or the edge of the bipolar plate. This gap can act as a 'secondary flow-field' (SFF) with unexpected results, which can be potentially advantageous or damaging to PEMFC performance $[19,20]$. This feature has been widely neglected in the literature. Figure 1 (a) shows the narrow gap between gasket and GDL in a generic fuel cell design. 


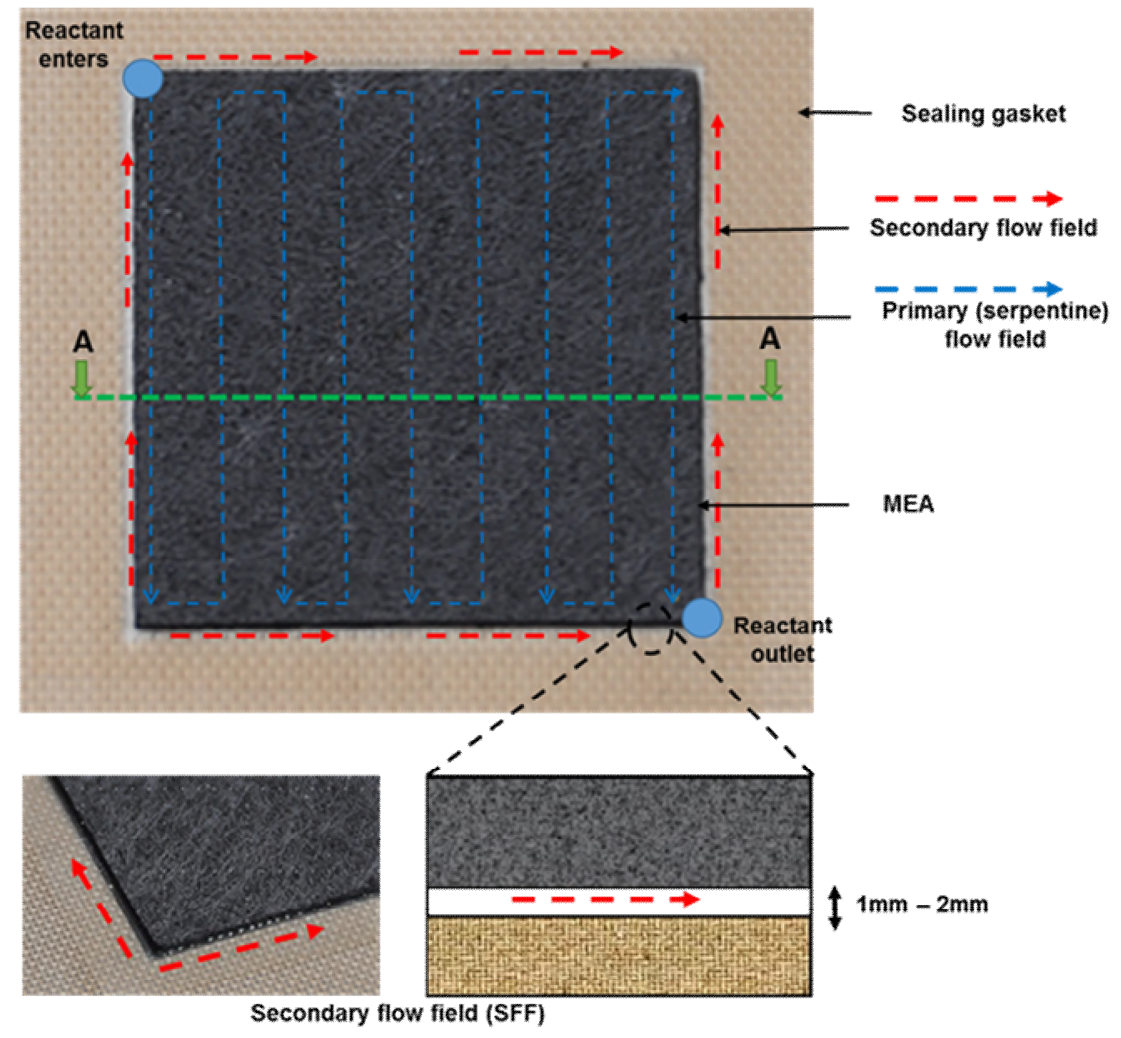

(a)
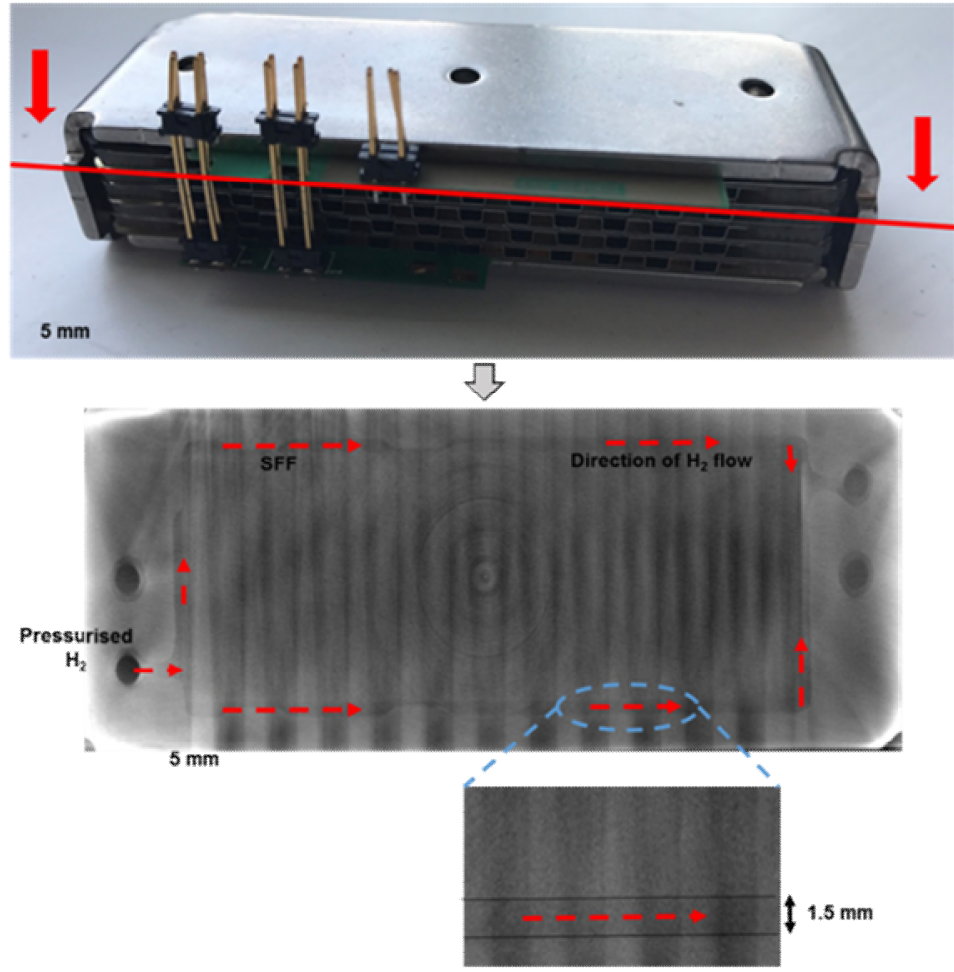

(b)

Figure $1 \mathrm{Cell}$ assembly process results in a thin gap between the MEA and a sealing gasket, referred as the 'secondary flow field' (a) SFF observed in the generic fuel cell design with serpentine flow field arrangement (b) X-ray computed radiographs of a commercial fuel cell showing the gap between gasket and membrane electrode assembly 
In the case of bipolar plate designs without a macroscopic (conventional) flow-field, the SFF offers a path of low resistance to reactant transport through the GDL [19]. In such designs, the reactant diffuses laterally through the GDL and the SFF may act as a primary flow-field [19]. As an example of how this is seen in technologically well-developed fuel cells, Figure 1(b) shows an X-ray radiograph of the internal structure of a commercial open-cathode fuel cell used in the UPP fuel-cell charger developed by Intelligent Energy, UK. A gap between the GDL and outer structure of the stack i.e. $1.5 \mathrm{~mm}$ wide SFF, is clearly visible and has been incorporated in the design architecture while dispensing conventional primary flow-field on anode side. The presence and extent of the SFF depends on the cell design, fabrication and assembly, GDL material, component positioning accuracy and the compression process.

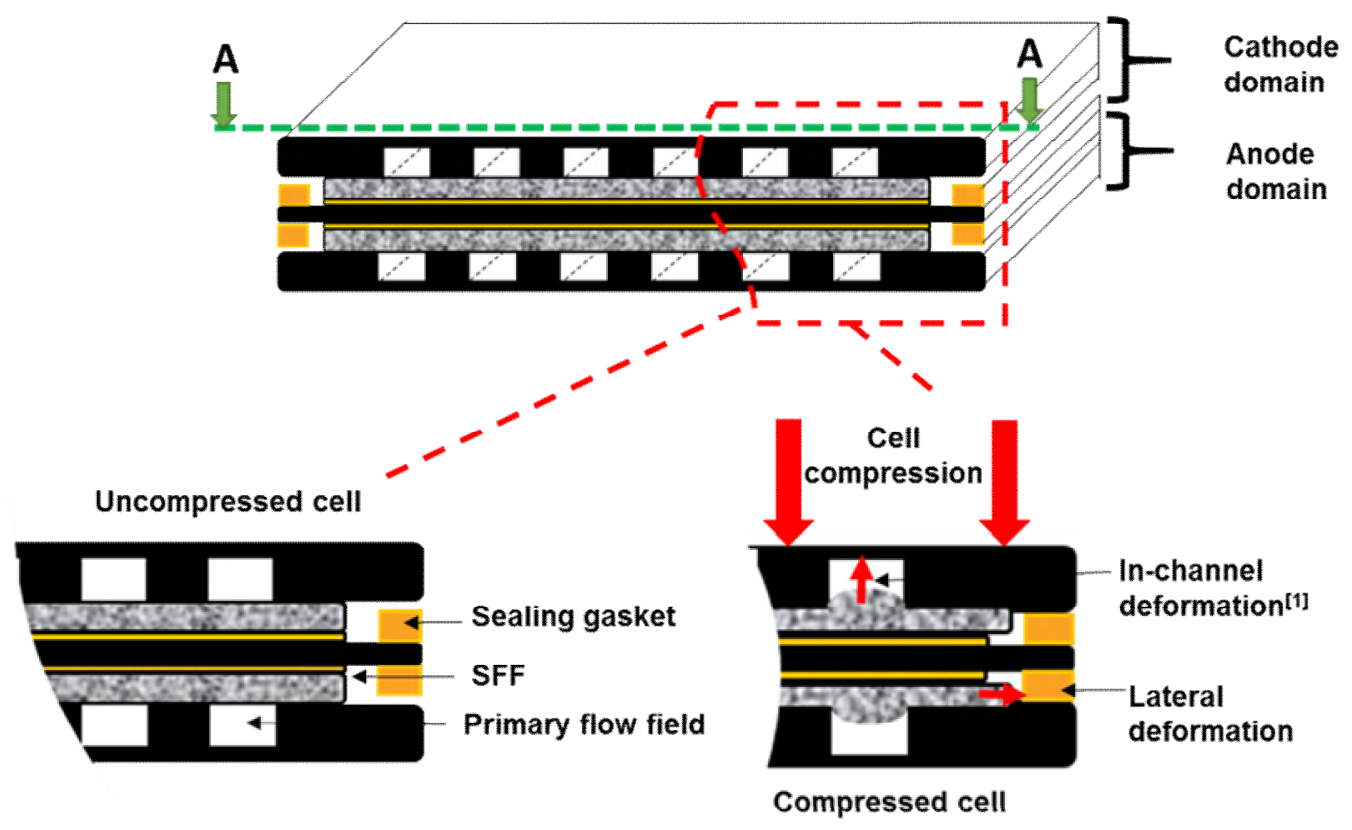

Figure 2 Schematic of the effect of cell compression during cell assembly process that results in the lateral and in-channel deformation of GDL in the primary and secondary flow field

\subsection{Fuel cell compression}

The optimal compression for a fuel cell depends on a range of factors, but the literature suggests that an optimal GDL compression that offers the best trade-off between sealing, reactant distribution and contact resistance is between 30\% - 50\% [21-25]; however, some designs go beyond this. For fuel cells containing a conventional 'primary' flow-field, increasing compression load results in constriction of the GDL under lands and potential protrusion of the GDL into the open channels, i.e 'tenting'. A numerous studies have been performed to analyse effect of non-uniform cell compression on the structural and morphological changes to the GDL, affecting parameters such as tortuosity, 
gas permeability, porosity, etc., however these studies focus mainly on the vertical deformation of the GDL under compression[22,23,25-31]. The same time, GDL compression leads to a certain amount of lateral deformation. In case of SFF, this could potentially narrow the SFF width, with GDL fibres protruding into the gap. This might result in the reduction of free convection path in the SFF and hence the reactant distribution to the active area, shown in Figure 2. The extent of GDL intrusion into the SFF due to cell compression should be known to properly size the MEA/GDL to either fill the SFF or control it and take advantage of SFF effects to improve the performance. To the authors' knowledge, there is no report that quantifies the lateral deformation of the GDL during cell compression.

\subsection{Dead ended anode operation in PEM fuel cells}

The cell operating modes and purge processes are another key factor that affects the performance of a fuel cell and has been the subject of research [19,32,33]. Dead-ended anode (DEA) mode is extensively used in commercial fuel cells where pressurised hydrogen is fed to the anode inlet, while the downstream anode valve is closed. This ensures the system operates at unit hydrogen stoichiometry[34-37].

The simplicity in the operation and higher fuel utilization makes DEA mode cost-effective and potentially more efficient than through-flow operation [38]. However, in practice, DEA operation can lead to the accumulation of back-diffused water and/or build-up of $\mathrm{N}_{2}$ due to its crossover from the cathode to the anode domain [33,38-40]. The areas of the anode lowest hydrogen concentration result in the greatest nitrogen blanket build-up of N2. This further the hydrogen starvation at the anode, voltage drop with time and uneven current density distribution [19,41,42]. The performance is regained by intermittently opening the purge valve[34,35,43,44]. The hydrogen humidification is the important water management parameter during DEA operation. While humid hydrogen stream results in water accumulation in anode as reported by various research groups[33,40], the dry hydrogen inlet could result in drying out the membrane while increasing cell temperature at subsequent domains[41]. Hence it is equally important to understand the cell drying process during DEA operation which would be affected by SFF design.

Y. Yang et.al studied the effect of anode flow-field arrangement on the DEA performance of the fuel cell, pointing out the type of anode flow-field arrangements impacts the fuel cell performance in DEA operation.[45] Flow-fields for DEA operation may, or may not, adopt a conventional 'primary' flowfield. The effect of an SFF on DEA operation is particularly pertinent, as when the exit valve is closed, access of reactant to the electrode is based on diffusion from the entrance point and not convective flow of gas through the flow-field. Systems that dispense with a flow-field altogether, such as the commercial fuel cell shown in Figure 1(b) rely on lateral diffusion of gas through the GDL alone; therefore, the presence of a SFF provides a lower resistance flow path around the circumference of 
the electrode, potentially improving reactant access. Therefore, the effect of SFF in an isolation from primary flow-field on anode side would develop the concrete knowledge regarding reactant distribution during DEA mode where SFF has been considered as a cell design feature.

\subsection{Numerical modelling and validation of dead ended anode operation}

Traditional experimental techniques, such as polarisation curves, offer good insight into the overall fuel cell operation but do not capure localised behaviour that can be achieved through numerical modelling. Recently numerous modelling studies focused on DEA operation and nitrogen and water build-up have been published [33,39,46-48] . Mainly these studies are 1D through the cell thickness or 2D where parallel channels are considered. These models provide the quantitative information regarding voltage performance, water accumulation and nitrogen blanketing in DEA operation however cannot predict the effect of flow-field arrangement including SFF on in-plane reactant distribution. Hence the simplistic model that shows the effect of SFF in an isolation from primary flow-field on the reactant distribution during DEA operation is needed[34]. The results can be validated using real-time visualisation techniques such as neutron imaging that identifies the water distribution in both the in-plane and through-plane directions $[9,20,49,50]$. The hydrographs developed shows the potential flooded and dry-out areas in the membrane. The neutron imaging performed by Meyer et al. [19] to study water distribution in transient DEA operation of the cell with SFF showed non-uniform water accumulation in the anode and non-uniform current and temperature distribution at the centre of electrodes.

This paper intents to identify the SFF as a potential design feature of fuel cells and highlight that it can potentially have an effect on performance. Secondly the effect of compression on lateral deformation of GDL has been studied using X-ray radiography that would influence the width of the SFF channel and need to consider while including SFF in the cell architecture. Thirdly a simplistic steady state half-cell CFD model is developed to investigate the effect of the presence and size of the SFF on flow and reactant distribution during DEA operation. This model is further validated against the published literature.

\section{X-ray radiography}

The sample GDL+MEA assembly used for this study were produced in-house using Nafion NRE212 membrane (Dupont, USA) as the electrolyte and ELE0201 Johnson Matthey gas diffusion electrodes (GDL coated with Pt. catalyst layer, $0.4 \mathrm{mg} \mathrm{Pt.} \mathrm{cm}^{-2}$ ). The active area of the MEA was 5 $\mathrm{cm}^{2}$. The MEA was hot-pressed (Carver $4122 \mathrm{CE}$, US) for $3 \mathrm{~min}$ at $130^{\circ} \mathrm{C}$ while a compressive load of 450 psi was applied. The cylindrical MEA samples were cut using a biopsy punch of $1.3 \mathrm{~mm}$ in diameter. The sample was mounted on a circular aluminium pistons of $3 \mathrm{~mm}$ diameter encapsulated in a Kapton tube. The assembly was then loaded in the compression rig for in-situ compression 


\subsection{Compression and $X$-ray imaging}

$X$-ray radiographs of the MEA during cell compression were obtained using a laboratory-based $X$ ray CT system, (Zeiss Xradia 520 Versa, Carl Zeiss X-ray Microscopy Inc., CA). An in-situ compression rig (CT500, Deben,UK) comprises of fixed top jaw, and motor controlled bottom jaw was used to apply the compression by defined displacement on a cylindrical sample encapsulated in the caption tube with a circular pin and punch type Al sample holder of diameter $3 \mathrm{~mm}$. This results in uniform sample compression between two flat plates. A source voltage of $80 \mathrm{kV}$, a field-of-view of $2 \mathrm{~mm}$ and $50 \mathrm{~s}$ exposure time were used for the image collection, giving $850 \mathrm{~nm}$ pixel dimensions at $0.4 \mathrm{x}$ magnification. A photograph of the compression stage and a compression sample holder is shown in Figure 3 (a) and (b), respectively. Figure 3 (c) shows the radiograph obtained in the uncompressed state. Different grey scale values depicts different material such as GDL, catalyst layer, membrane, and the aluminium compression pins.

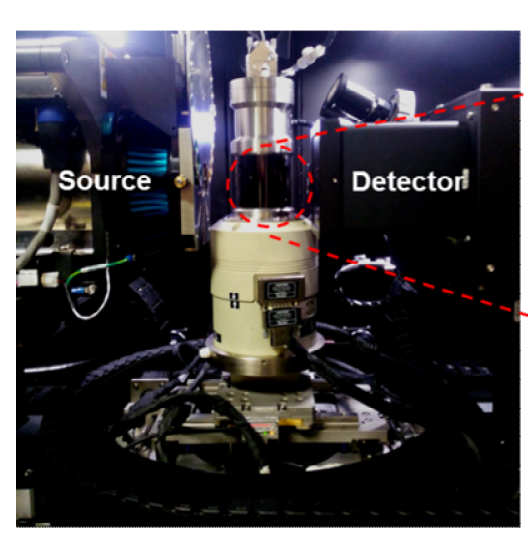

(a)

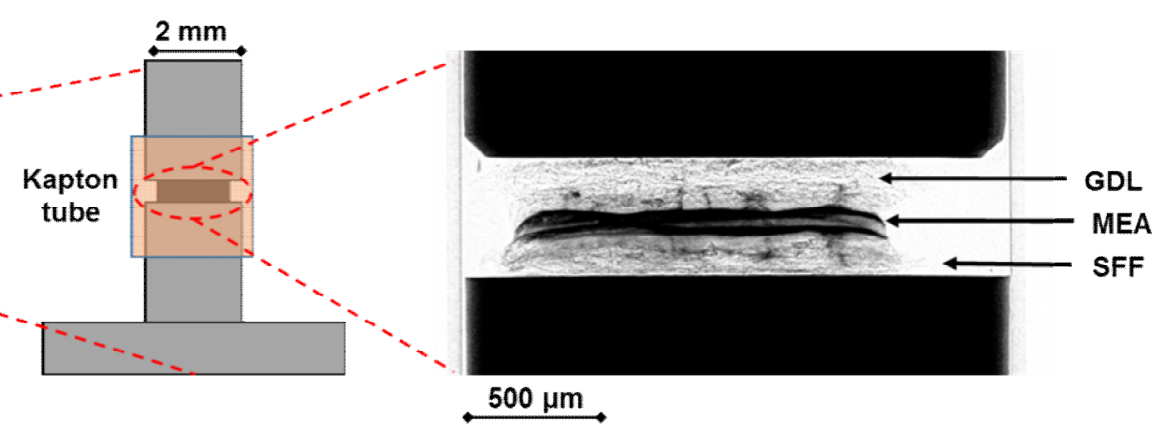

(b) (c)

Figure 3 Set-up for imaging of GDL compression: (a) compression stage, (b) the circular pins of $2 \mathrm{~mm}$ diameter enclosed in a Kapton tube was used for the compression with the GDL sample placed at the centre.,(c) X-ray radiograph of uncompressed sample.

The cell compression by displacement using the Deben Microtest module is applied by movement in the $y$-direction of the circular pin, and the compression is given by ratio of the distance between the pin and the punch ( $H_{G D L}^{\text {Compressed }}$ ) to the original / uncompressed thickness of the cell $\left(H_{G D L}^{\text {Uncompressed }}\right)($ Eq. 1). Compresstion varies from $0 \%$, i.e. no compression, to $80 \%$, in steps of $10 \%$.

Compression $(\%)=\frac{H_{G D L(+M E A)}^{\text {Uncompressed }}-H_{G D L(+M E A)}^{\text {Compressed }}}{H_{G D L(+M E A)}^{U n \operatorname{compred}}}$

On imaging completion, the radiographs were reconstructed (Reconstructor Scout-and-Scan, ZEISS). The image processing of the acquired images was performed using Avizo Lite® (FEI) and Fiji/ImageJ open code. Three distinct phases were identified such as the Al pins (black), carbon fibre phase, i.e. GDL/MEA assembly (grey) and empty space that represents the SFF (white). 


\subsection{Lateral expansion of MEA under compression}

The amount of GDL intrusion into the perimeter channel when under compression should be known in order to properly size the MEA/GDL to either fill the space or control it and take advantage of SFF effects to improve performance. The radiographic images of four different levels of cell compression are shown Figure 4(a). The radiographs show the increase in material density in the cell with increased compression. Figure 4(b) shows the extent of lateral deformation into the SFF space under uniform cell compression.

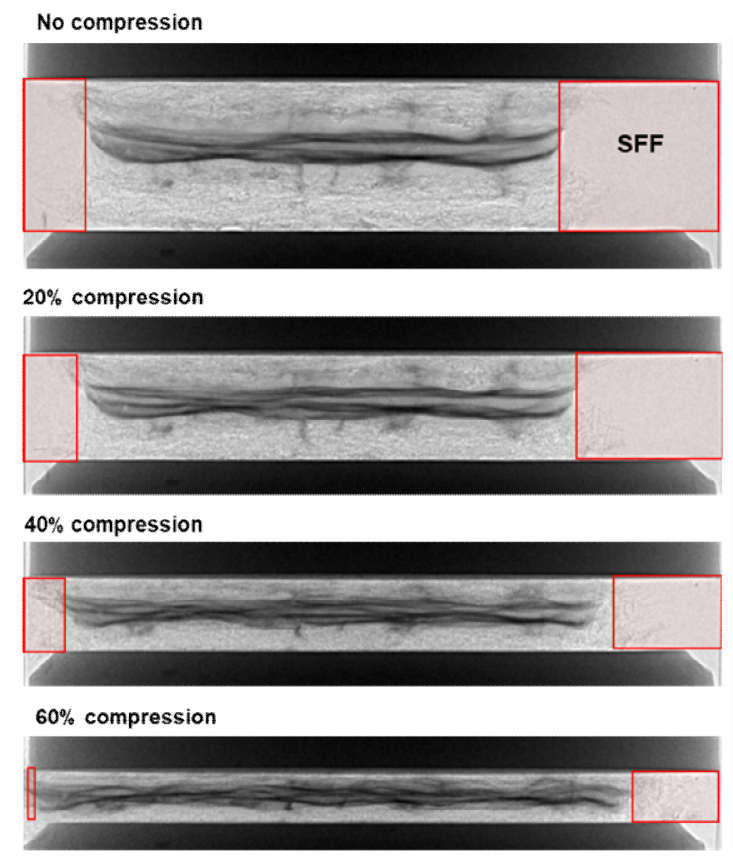

(a)

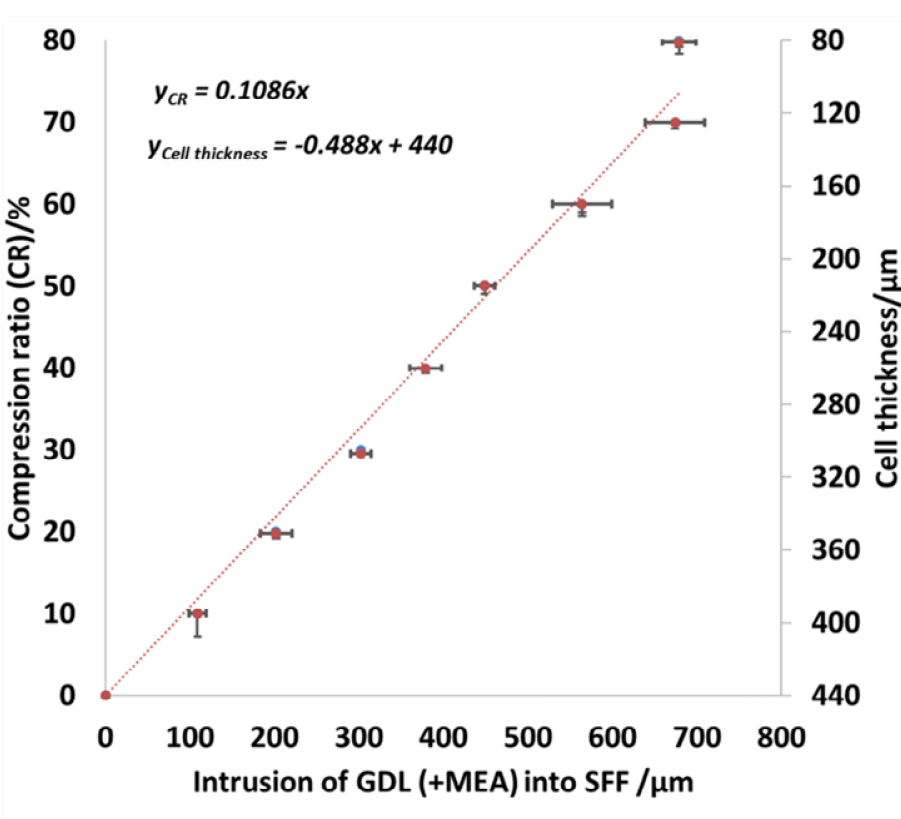

(b)

Figure 4 (a) Radiographs of the cell compression at variable cell compression from $0 \%$ to $60 \%$ showing intrusion of GDL into the SFF; (b) quantitative representation of intrusion of GDL/MEA into the SFF (calibration graph).

The results show that the uniformly compressed GDLs deform laterally, leading to reduced free-path of reactant. To serve as an approximate design parameter, a linear fit to these data over the range of $0-60 \%$ (the range over which a GDL would typically be compressed) gives a value of $0.1086 \%$ $\mu \mathrm{m}^{-1}$ lateral deformation of the GDL.

\section{Computational modelling}

The performance of a fuel cell strongly depends upon the operating conditions, transport phenomena and electrochemical reaction kinetics. Reactant distribution is crucial in deciding species transport in a cell, which is largely affected by the flow-field design. This work forms the basis for developing 
computational tools to understand and optimise the use of the SFF to improve fuel cell design and operation.

\subsection{Computational domain and assumptions}

The computational domains used for the study, along with boundary labels are shown in Figure 5. The following key assumptions were made in the model:

1. The low temperature PEM fuel cell operates under steady-state isothermal condition at $60^{\circ} \mathrm{C}$ (as is common for open-cathode PEMFCs).

2. The current model solves mass, momentum and energy conservation equations, along with species conservation

3. The anode domain has a fixed average current density ' $j$ ' that acts as the reactant sink, modelled using the Butler-Volmer equation.

4. The single phase flow in the (secondary) flow-field was laminar.

5. The momentum interactions between the fluid and porous phases were modelled using Darcy's law and the species diffusion modelled using Maxwell-Stefan's law.

6. GDL, catalyst layer, and the membrane were assumed isotropic and homogeneous

7. The membrane was considered impermeable for reactant gases; hence, the accumulation of back diffused water and effect of gas crossover was neglected.

8. The model assumes dry $\mathrm{H}_{2}$ supplied at the inlet at constant pressure and unit stoichiometry.

9. The fuel cell is open-cathode with high cathode stoichiometry; hence, the effect of cathode oxygen depletion are not solved in the modelling.

10.

effect of cell compression on the morphological properties of GDL, CL or membrane is not considered in the modelling

\subsection{Boundary conditions}

Table 1 lists the parameters used in the model. The anode was supplied with dry pressurised $\mathrm{H}_{2}$ at 300 mbar. The dead-ended anode (DEA) condition, i.e. purge valve closed condition, was mimicked with a wall boundary condition at the anode outlet. The rectangular geometry of the anode domain offered symmetrical anode flow behaviour. Hence, to optimise computational time, symmetry in the $x$ - $z$ plane was employed. 


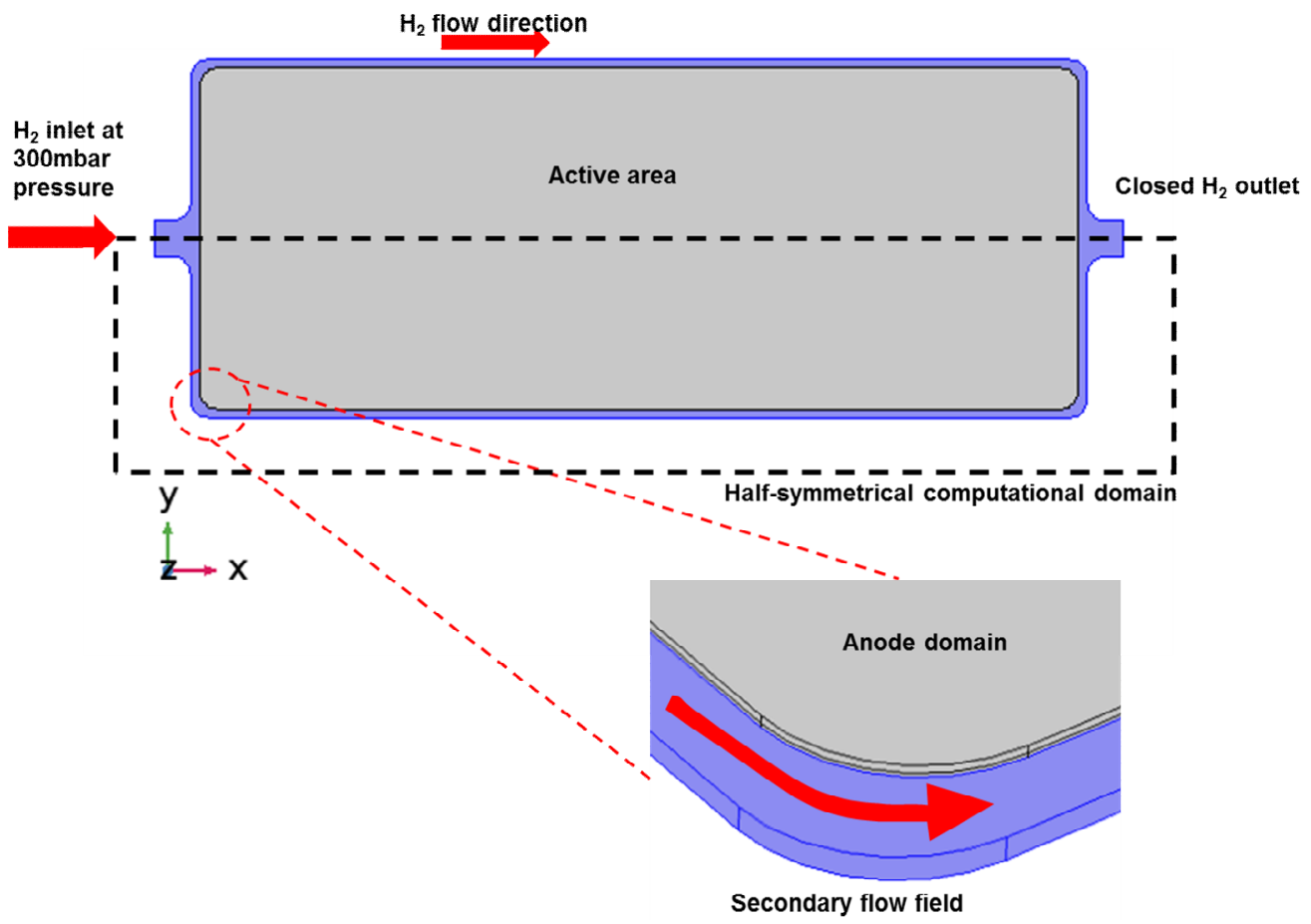

Figure 5 3-dimensional computational domain from $x-y$ planer view and detailed view of the SFF.

The no-slip boundary condition was applied to the flow-field walls and slip-wall boundary condition to the porous walls. The parametric investigation solves for four SFF design cases: case (i) design without the SFF, i.e. either no primary anode flow-field is used and the SFF is blocked due to the lateral deformation of GDL fibres; case (ii) design with $0.1 \mathrm{~mm}$ SFF is available; case (iii) design where $0.25 \mathrm{~mm}$ SFF is available, and case (iv) design with $1 \mathrm{~mm}$ wide SFF is available for the reactant transport. The model was tested under various operating current densities ranging from 0.1 $A \mathrm{~cm}^{-2}$ to $1 \mathrm{~A} \mathrm{~cm}^{-2}$. The current work discusses the results for three average current densities, i.e. $0.1 \mathrm{~A} \mathrm{~cm}^{-2}, 0.6 \mathrm{~A} \mathrm{~cm}^{-2}$ and $1 \mathrm{~A} \mathrm{~cm}^{-2}$. These current densities were carefully chosen as fuel cell reactant transport dynamics typically become important over $0.6 \mathrm{~A} \mathrm{~cm}^{-2}$ and leads to voltage decay during DEA operation [19]. All the cases are initialised at $0.6 \mathrm{~V}$ for the computational stability. 


\section{Table 1}

\section{Property}

Current density (J)

GDL Thickness - 40\% compression ( $\left.H_{G D L}^{\text {Compressed }}\right)$

GDL Thickness - 60\% compression $\left(H_{G D L}^{\text {Compressed }}\right)$

GDL Thickness - 70\% compression ( $\left.H_{G D L}^{\text {Compressed }}\right)$

Membrane thickness $\left(H_{m e m}\right)$

Catalyst layer thickness $\left(H_{c l}\right)$

GDL porosity - $20 \%$ compression (Por Comp $_{\text {Coressed }}$ )

GDL porosity - 40\% compression (Por Comp $_{\text {Coressed }}$ )

GDL porosity - 60\% compression (Por Comp $_{\text {Cosed }}$ )

Catalyst layer porosity $\left(\mathrm{Por}_{c l}\right)$

Catalyst layer permeability $\left(K_{c l}\right)$

GDL permeability $\left(K_{g d l}\right)$

GDL electrical conductivity $\left(\sigma_{g d l}\right)$

Electrolyte conductivity $\left(\sigma_{m e m}\right)$

$\mathrm{H}_{2}$ Viscosity $(\mu)$

$\mathrm{H}_{2}$ inlet pressure $\left(P_{\text {in }}\right)$

Cell operating temperature $(T)$

Reference $\mathrm{H}_{2}$ concentration

Anode exchange current density $\left(i_{o}^{a}\right)$

Anodic transfer coefficient $\left(\alpha_{a}\right)$

Cathodic transfer coefficient $\left(\alpha_{c}\right)$
$0.1,0.6,1\left[\mathrm{~A} \mathrm{~cm}^{-2}\right]$

$1.00 \times 10^{-4}[\mathrm{~m}]$

$0.55 \times 10^{-4}[\mathrm{~m}]$

$0.40 \times 10^{-4}[\mathrm{~m}]$

$40 \times 10^{-6}[\mathrm{~m}]$

$15 \times 10^{-6}[\mathrm{~m}]$

0.75

0.6

0.5

0.3

$1 \times 10^{-13}\left[\mathrm{~m}^{2}\right]$

$1.76 \times 10^{-11}\left[\mathrm{~m}^{2}\right]$

570 [S m $\left.{ }^{-1}\right]$

$9\left[\mathrm{~S} \mathrm{~m}^{-1}\right]$

$1.19 \times 10^{-5}[\mathrm{~Pa} \mathrm{~s}]$

300 [mbar]

$333\left[{ }^{\circ} \mathrm{K}\right]$

$40.89\left[\mathrm{~mol} \mathrm{~m}^{-3}\right]$

$1 \times 10^{-4}\left[\mathrm{~A} \mathrm{~m}^{-2}\right]$

0.5

0.5

\subsection{Governing equations}

The computational model consists of the following governing equations with respect to individual components in the computational domain. 


\subsubsection{Secondary flow-field}

Based on the assumptions made in the current model, the reactant, i.e. pressurised hydrogen flowing through the SFF, is governed by the continuity equation. The steady-state Navier-Stokes equation describes the momentum conservation for an incompressible fluid.

$\boldsymbol{\rho}(\mathbf{u} \cdot \boldsymbol{\nabla}) \mathbf{u}=\boldsymbol{\nabla} \cdot\left[-\mathbf{P I}+\boldsymbol{\mu}\left(\boldsymbol{\nabla u}+\nabla \mathbf{u}^{\mathbf{T}}\right)\right]$

$\boldsymbol{\nabla} \cdot \mathbf{u}=\mathbf{0}$

Here, $\mathrm{u}$ is the velocity vector, $\left(\mathrm{m} \mathrm{s}^{-1}\right) ; \mu$ is the dynamic viscosity, $\left(\mathrm{kg} \mathrm{m}^{-1} \mathrm{~s}^{-1}\right) ; P$ is the pressure, $(\mathrm{Pa}) ; \rho$ is the density of the gas mixture, $\left(\mathrm{kg} \mathrm{m}^{-3}\right)$. It is described by,

$\rho=\frac{P \cdot \sum_{i} x_{i} M_{i}}{R T}$

Where $x_{i}$ is the mole fraction; $\mathrm{R}$ is the universal gas constant, $8.314\left(\mathrm{~J} \cdot(\mathrm{mol} \mathrm{K})^{-1}\right) . T$ is the cell operating temperature $(\mathrm{K})$. The subscript $i$ represents species used in the model, i.e. hydrogen and water. The species diffusion and conservation in the SFF were defined using the Maxwell-Stefan diffusivity equation. This solves for the mass fraction fluxes.

$j_{i}=-\left(\rho D_{i}^{m} \nabla \omega_{i}+\rho D_{i}^{m} \omega_{i} \frac{\nabla m_{n}}{m_{n}}\right) \nabla \cdot j_{i}+\rho(u \cdot \nabla) \omega_{i}=R_{i}$

Where $D_{i}^{m}=\frac{1-\omega_{\mathrm{i}}}{\sum_{\mathrm{k} \neq \mathrm{i}} \frac{x_{\mathrm{k}}}{\overline{\mathrm{ik}}_{\mathrm{k}}}}$ and $D_{i k}$ is the diffusion coefficient, $\left(\mathrm{m}^{2} \mathrm{~s}^{-1}\right), R_{i}$ is the reaction rate, $\left(\mathrm{kg} \mathrm{m}^{-3} \mathrm{~s}^{-1}\right)$. As no reaction takes place in the flow-field, $R_{i}=0 . x$, the mass fraction, and $M$, is the molecular mass of the species $\left(\mathrm{kg} \mathrm{mol}^{-1}\right)$.

\subsubsection{GDL and catalyst layer}

GDL and catalyst layers are considered porous domains. Hence, the velocity distribution is solved using Darcy's mass conservation equation.

$-\frac{k}{\mu} \nabla \cdot p=u$

Where $k$ is the permeability $\left(\mathrm{m}^{2}\right)$ and the continuity equation is given by:

$\nabla \cdot(\rho u)=S$

Here, $S$ is the source term, $\left(\mathrm{kg} \mathrm{m}^{-3} \mathrm{~s}^{-1}\right)$. The continuity equation for gas flow in the anode domain is defined by the sum of hydrogen and water present at the anode. The source term, $S$, defines the total production and consumption of the species during the electrochemical reactions. The reaction rate, $R_{i}$, is defined in the catalyst layer. This is solved using Faraday's law.

$\boldsymbol{R}_{\mathrm{H}_{2}}=-\frac{j_{a}}{2 \boldsymbol{F}} \mathbf{M}_{\mathrm{H}_{2}}$ 


\subsubsection{Electrochemical reaction}

The electrochemical reaction (species sink equivalent to current) at the anode catalyst layer is formulated by the anodic Butler-Volmer expression.

$j_{a}=i_{o}^{a}\left(\exp \left(\frac{\alpha_{a} \mathrm{~F} \eta}{R T}\right)-\exp \left(\frac{-\alpha_{c} \mathrm{~F} \eta}{R T}\right)\right)$

Where $i_{o}^{a}$ is the anode exchange current density, $\left(\mathrm{A} \mathrm{m}^{-2}\right) ; \alpha_{a}$ and $\alpha_{c}$ are anodic and cathodic transfer coefficients respectively. $\eta$ is electrochemical overpotential $(\mathrm{V})$; which is expressed by the potential difference between the solid phase responsible for electron transport and electrolyte phase responsible for proton transport. The anode side electrochemical overpotential is defined as,

$\eta=\phi_{s}-\phi_{l}$

The current model performs parametric analysis at average current density boundary condition set at $0.1,0.6$ and $1 \mathrm{~A} \mathrm{~cm}^{-2}$.

\subsection{Numerical solution}

The system of coupled nonlinear equations contain five dependent variables, electrolyte potential $\left(\phi_{l}\right)$, an electric potential $\left(\phi_{s}\right)$, velocity $(u$,$) , pressure (P)$, and mass fraction $\left(\omega_{i}\right)$ at the anode. All the partial differential equations in this model were solved in the commercial software environment, COMSOL Multiphysics 5.2a on a desktop computer with $2.67 \mathrm{GHz}$ and $128 \mathrm{~GB}$ RAM. All PDEs were solved using a direct solver, MUMPS, with undamped Newton and relative tolerance of $10^{-6}$ was used as the convergence criteria. Due to the small curvatures in the geometry, in the present work, a triangle grid based on the Lagrange shape function was generated for finite-element calculation with average mesh quality of 0.54 . Mesh independency was checked by solving a base-case study using three different mesh densities. For the channel-level study, three SFF channel sizes consisting of 411800,457555 and 503310 elements were implemented. $1 \%$ deviation was observed in terms of local velocity, pressure and species molar concentration. Hence, the grid independent mesh density of 457555 was selected as a good trade-off between result accuracy and computational time.

\subsection{Modelling results}

The objective of the numerical modelling was to predict the effect of the available SFF on the localised reactant distribution at the anode. This work focuses on the system with no macroscopic (primary) flow-field. The current model shows the effect of available SFF on the localised reactant velocity and the molar concentration. 


\subsubsection{Effect available SFF on the localised velocity distribution}

Figure 6 (a) shows a matrix of results describing the effect of the width of SFF on the localised planar velocity at the GDL mid-plane ( $x y$ plane) at varying current densities. During DEA operation, the system works at unit stoichiometry; hence, the $\mathrm{H}_{2}$ mass flux increases with increase in the current density, manifest here by an increase in diffusion velocity.

For Case (i), design without SFF, at a lower current density $\left(j=0.1 \mathrm{~A} \mathrm{~cm}^{-2}\right)$, the planar velocity at the GDL mid-plane is comparatively even. Increasing to $j=0.6 \mathrm{~A} \mathrm{~cm}^{-2}$, linear velocity gradient across the GDL was observed to accommodate the increased consumption of $\mathrm{H}_{2}$. At $j=1 \mathrm{~A} \mathrm{~cm}^{-2}$, velocity gradient across the GDL has further increased. This shows that $\mathrm{H}_{2}$ is diffusing through the GDL from the point of entry.

Case (ii) describes a $0.1 \mathrm{~mm}$ wide SFF. Though the results show a similar trend as for Case (i) at lower current density, with an increase in current density, a transition from a 'diffusion-driven flow' regime to the convective mass transport around the perimeter of the cell and diffusive mass transport into the GDL becomes increasingly apparent.

For Case (iii), i.e. $0.25 \mathrm{~mm}$ wide SFF, an approximately constant convective velocity in the SFF is observed, servicing the $\mathrm{H}_{2}$ sink within the active electrode area. At higher current density, this design shows the shift in lower diffusion velocity region towards the centre of the electrode, as highlighted in Figure 6 (a-1) and (b-2).

Case (iv) shows the design with a $1 \mathrm{~mm}$ SFF. At lower current density, this design shows similar planer velocity distribution to Case (iii). With the increase in the average current density, the effect of the SFF is evident. At $j=1 \mathrm{~A} \mathrm{~cm}^{-2}$, a greater velocity gradient into the centre of the electrode was observed. This results in the lower diffusion velocity region at the centre, highlighted in Figure 6 (a3) and (b-4).

The velocity vector plots are shown in Figure 6 (b) support the planer velocity contour plots and emphasises the effect of the SFF on the reactant transport. 


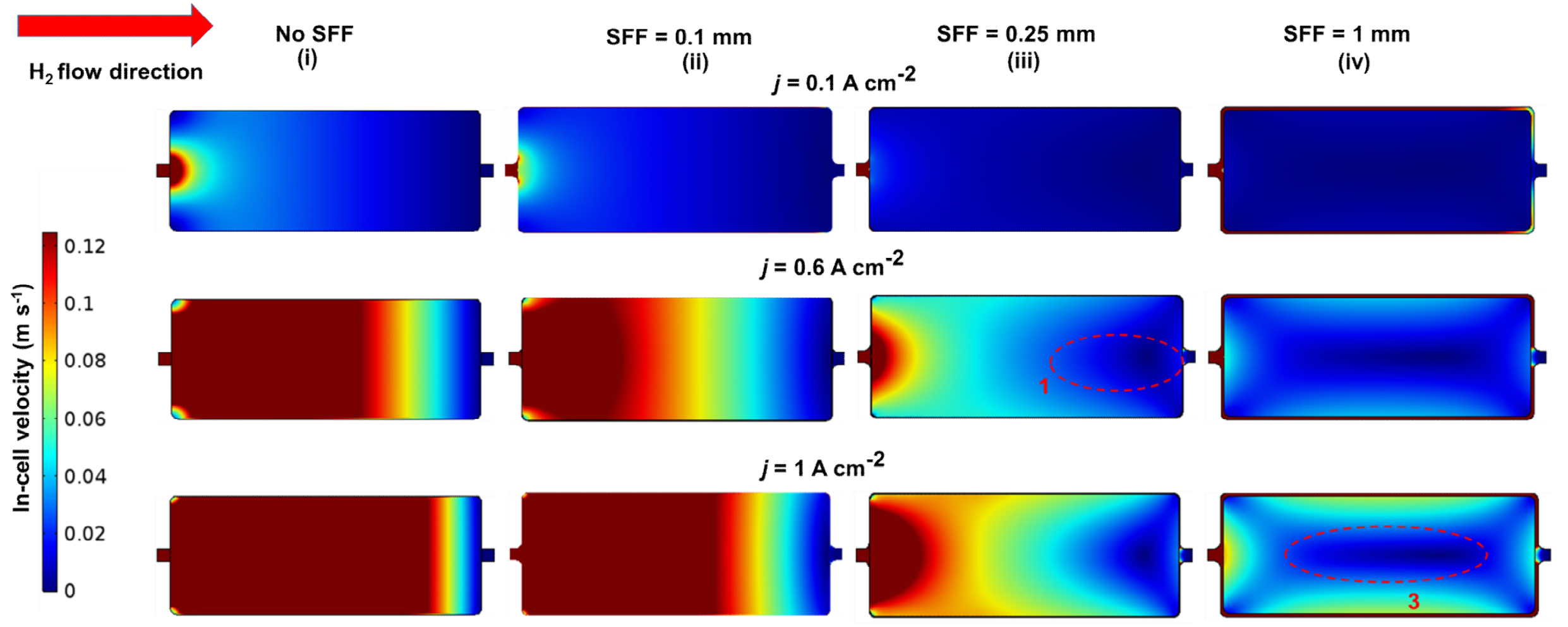

(a)

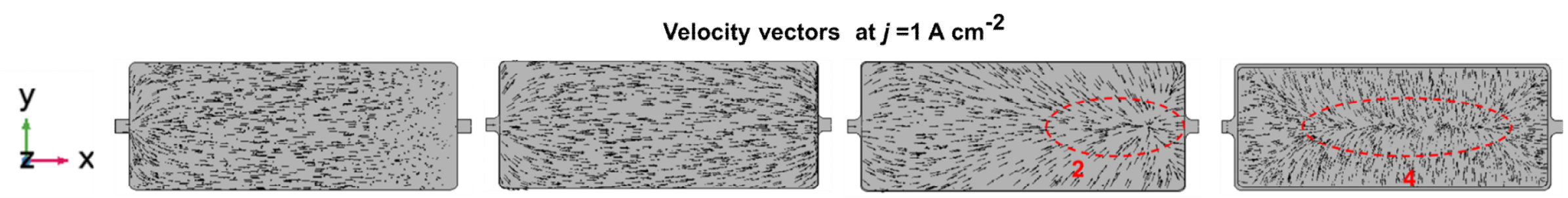

(b)

Figure 6 Effect of current density and SFF design on in-cell hydrogen velocity distribution at the GDL-mid plane while operating in dead-ended mode for: (i) design without SFF; (ii) SFF width $=0.1 \mathrm{~mm}$; (iii) SFF width $=0.25 \mathrm{~mm}$ and (iv) SFF width $=1 \mathrm{~mm}$. (a) Planer velocity contours at variable current density and (b) velocity vector plots at $j=1 \mathrm{~A} \mathrm{~cm}^{-2}$ 


\subsubsection{Effect available SFF on localised reactant concentration}

The current fuel cell design relies on the lateral flow of reactant through the anode GDL, the SFF effectively acts as the 'primary' flow-field, ensuring reactant distribution from all the sides of the GDL. Figure 7 (a) shows global hydrogen concentration at the relatively high average current density of $j$ $=1 \mathrm{~A} \mathrm{~cm}^{-2}$ during DEA operation .

As observed, the presence of the SFF has a major effect on the localised hydrogen concentration. The hydrogen concentration gradient is defined as the ratio of the difference between concentration $\left(C_{\text {inlet }}^{\text {Max }}-C^{\text {min }}\right)$ at the GDL mid-plane to the maximum concentration at the inlet $\left(C_{\text {inlet }}^{\text {Max }}\right)$ and acts as an indication of how evenly distributed the reactant is across the electrode. Figure 7 (b)

Hydrogen concentration gradient $(\%)=\frac{\left(C_{\text {inlet }}^{\text {Max }}-C^{\text {min }}\right)}{C_{\text {inlet }}^{\text {Max }}}$

Case (i) shows the reactant distribution without a SFF. This design has the highest hydrogen concentration gradient among all the designs at 38.0\%, which implies a more uneven reactant distribution. In Case (ii), $0.1 \mathrm{~mm}$ SFF, a greater hydrogen concentration gradient was observed with $15.8 \%$ overall concentration depletion from the inlet to close to a minimum close to the 'exhaust' location. For Case (iii), though the results show a similar trend as for Case (ii), this design shows more of the effect of the combined convective - diffusive flow on the localised hydrogen concentration distribution, with the reduction in concentration gradient to $5.6 \%$. This design shifts the localised reactant concentration minima slightly from the exhaust location towards the centre (to the 'left') of the electrode( Figure 7 (a) ). Case (iv) describes the reactant distribution behaviour of the cell with a $1 \mathrm{~mm}$ wide SFF channel. This design shows comparatively even reactant distribution with the reduction in concentration gradient to $1.1 \%$ when compared at the global colour scale

As the common legend of the $3 \mathrm{D}$ contour plots fails to show the interesting localised concentration features, case iv with local concentration legend shows the local minima of hydrogen concentration has moved to the the center of the cell outlet. The yz and zy planer concentration shown in Figure 7 (d) shows concentration varies has mainly in in-plane direction with constant concentration in through plane direction as shown in the detailed view. In current design wdominated with SFF flow enters in GDL lateral direction hence the effect of through plane permeability and throughplane diffusivity has shown minimal effect on the reactant distribution. 


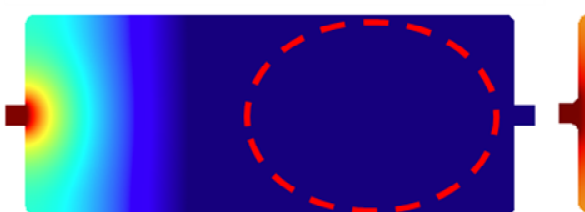

Case i- No SFF

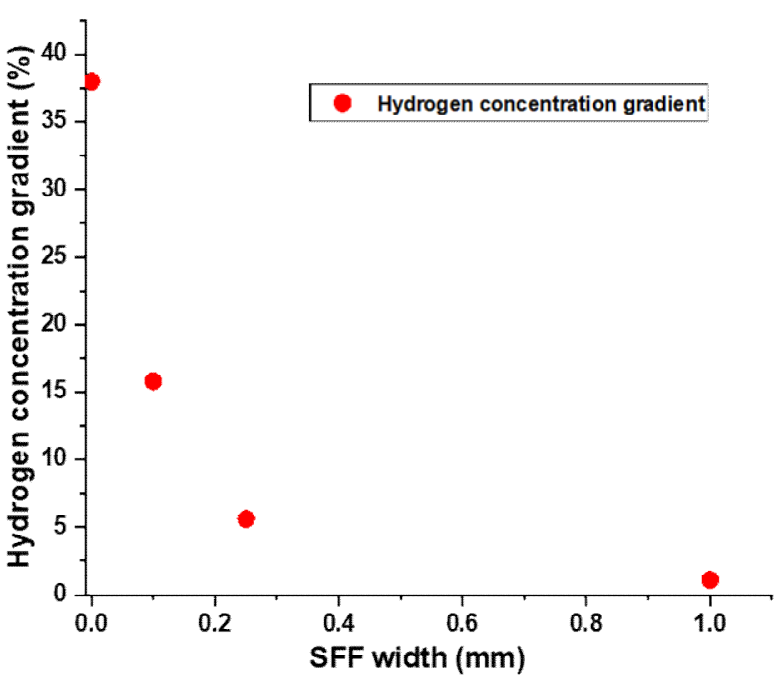

(b)

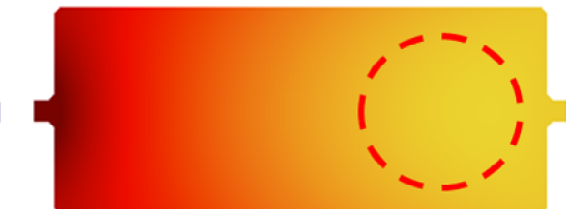

Case iii- $0.25 \mathrm{~mm}$ SFF

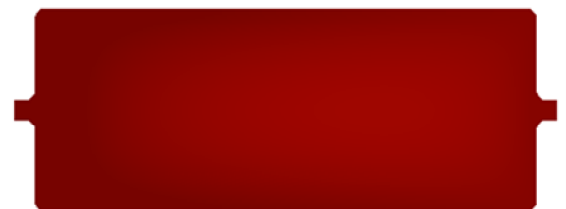

Case iv- 1 mm SFF

(a)
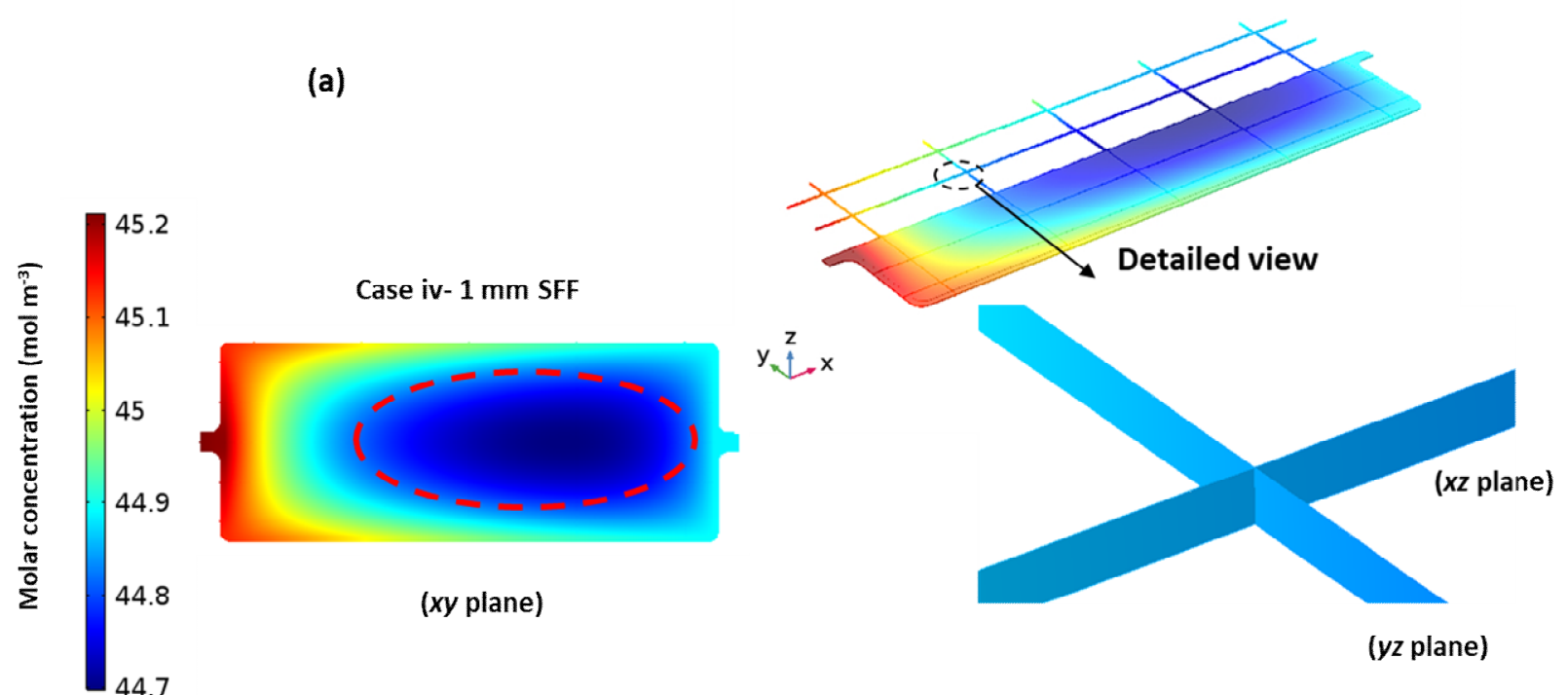

(c)

(d)

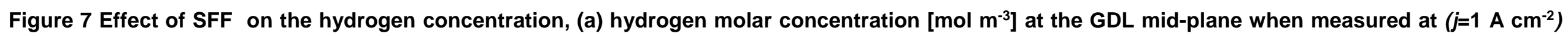

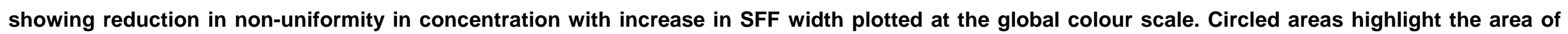

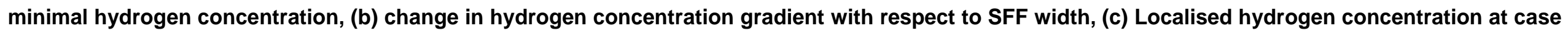
iv, SFF width $1 \mathrm{~mm}$, (d) in-plane and through plane hydrogen concentration plot, detailed view showing the uniform through=plane concentration. 


\subsubsection{Validation}

Recently, Watanabe et al. used a visualisation techniques to investigate localised hydrogen concentration distribution for the cell with SFF dominant flow-field design, mentioned as 'wraparound flow paths' [54]. The results supports the lateral diffusion of the hydrogen from the perimeter results in lower hydrogen concentration area at the central part of the outlet side as shown in Figure 7 case iv,

Figure 8 (a) shows the hydrographs developed during the neutron imaging study performed by Meyer et al. [19] at through-flow and DEA operation. The cell design used shares the features with that modelled here, no conventional flow-field at the anode and the presence of a $1 \mathrm{~mm}$ wide SFF. The dry pressurised hydrogen was supplied at the hydrogen inlet. The hydrographs obtained shows the cell drying at the centre of the cell highlighted by the modelling as low hydrogen velocity region shown in Figure 6 (a), at $1 \mathrm{~mm}$ wide SFF operating at $0.6 \mathrm{~A} \mathrm{~cm}^{-2}$ current density.

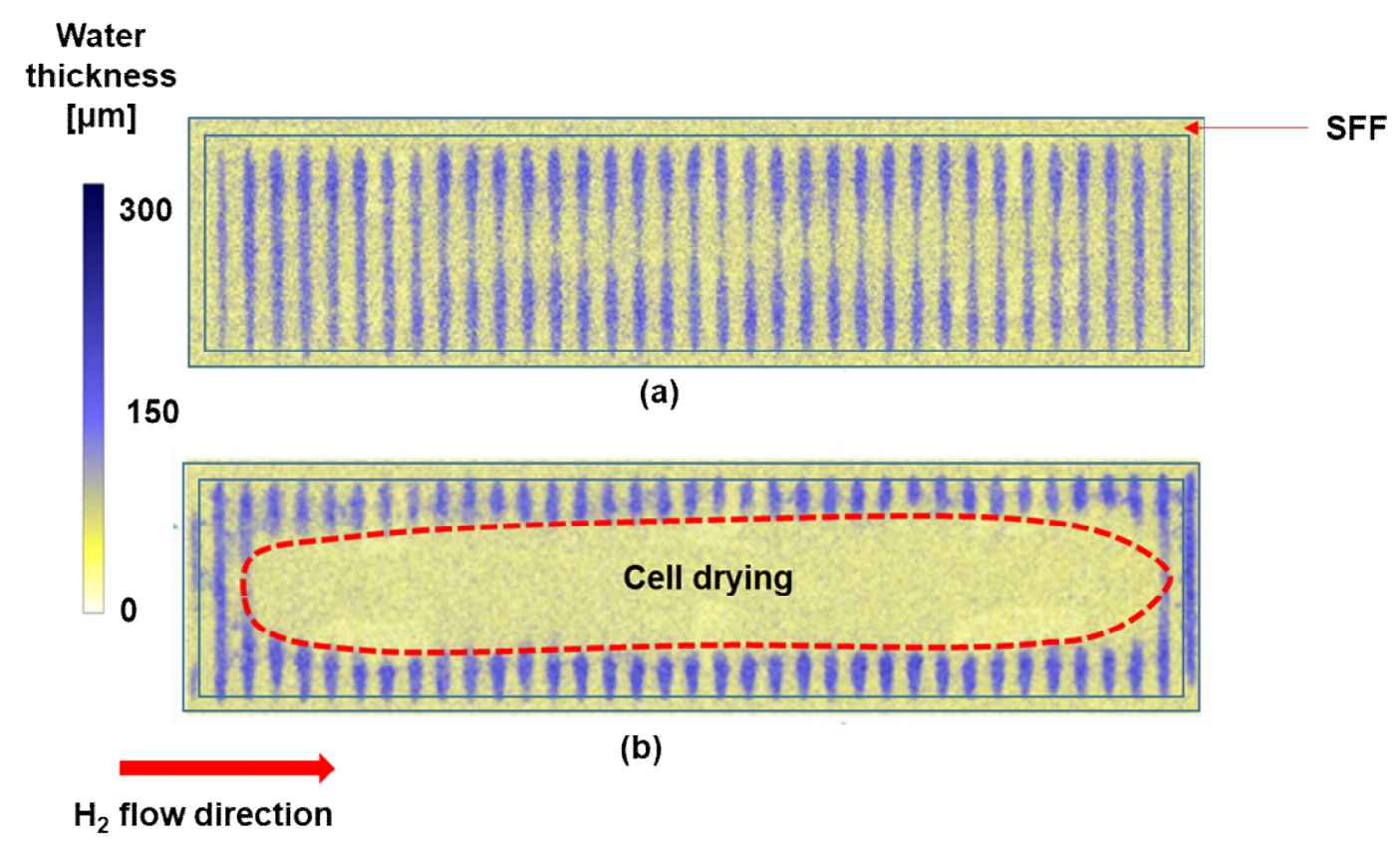

Figure 8 Neutron hydrographs in xy plane at the centre of the cells, with no conventional flow-field at the anode, where SFF acts as a primary flow-field and cross-flow at the cathode, $j=0.56 \mathrm{Acm}^{-2}$. (a) through flow operation, (b) DEA operation results in depletion of water in the middle of the electrode, resulting in subsequent cell drying and $\mathrm{H}_{2}$ starvation, Adapted from [19]

\section{Conclusion}

This work identifies the gap that may exist at the perimeter of a GDL as a 'secondary' flow-field. The way in which an MEA is put into compression, causes the GDL to expand laterally by different amounts and will determine the width of the SFF channel. X-ray radiography of an MEA has shown approximately linear lateral intrusion of the GDL into the gap with increasing compression. 
The influence of the SFF dimension on reactant distribution in an operating fuel cell is explored by applying a simple electrochemical/flow model. However, it is important to note that the present model solves steady-state, dead-ended operation, with constant current output. In reality, PEMFC operation is transient and the anode will suffer from $\mathrm{N}_{2}$ crossover from the cathode. Such multiphase and transient response factors are likely to lead to more complex operation in practice.

In the specific case of a fuel cell operating without a conventional anode flow-field in dead-ended mode, the presence of a SFF is predicted to improve reactant distribution and consequently current density distribution. In the cell where both primary and secondary flow-fields are available, the SFF would enhance the overall reactant distribution and complement the behaviour of primary or conventional flow field during DEA operation. Studies using current mapping would allow these predictions to be further examined.

The way that the SFF forms will depend on the compression of the fuel cell and the manufacturing and component tolerances. There is scope for optimising the SFF for operation and modifying its structure by, for example, incorporating baffle features or tapering the channel width to facilitate reactant access to the active electrode area.

\section{Acknowledgement}

The authors would like to acknowledge funding from the EPSRC (EP/L015277/1, EP/P009050/1, EP/M014371/1, EP/M009394/1, EP/M023508/1, EP/L015749/1, EP/N022971/1) for supporting fuel cell research in the Electrochemical Innovation Lab (EIL) and to the Digital Engineering and Test Centre (APC Spoke) Virtually Connected Hybrid Vehicle (VCHV) project for supporting Kulkarni. Shearing acknowledges the Royal Academy of Engineering Chair in Emerging Technologies.

\section{References}

[1] Barbir F. PEM Fuel Cells: Theory and Practice. Strateg Manag J 2005;22:314. doi:10.1016/B9780-12-387710-9.00012-6.

[2] O’Hayre, R., Cha, S.W., Colella, W., Prinz FB. Fuel cell fundamentals. Second. New York: John Wiley \& Sons, Inc.; 2006.

[3] Li X, Sabir I. Review of bipolar plates in PEM fuel cells: Flow-field designs. Int J Hydrogen Energy 2005;30:359-71. doi:10.1016/j.ijhydene.2004.09.019.

[4] Shimpalee S, Van Zee JW. Numerical studies on rib \& channel dimension of flow-field on PEMFC performance. Int J Hydrogen Energy 2007;32:842-56. doi:10.1016/j.ijhydene.2006.11.032.

[5] Li W, Zhang Q, Wang C, Yan X, Shen S, Xia G, et al. Experimental and numerical analysis of a 
three-dimensional flow field for PEMFCs. Appl Energy 2017;195:278-88.

doi:10.1016/j.apenergy.2017.03.008.

[6] Brett DJL, Brandon NP. Review of Materials and Characterization Methods for Polymer Electrolyte Fuel Cell Flow-Field Plates. J Fuel Cell Sci Technol 2007;4:29. doi:10.1115/1.2393303.

[7] Anderson R, Zhang L, Ding Y, Blanco M, Bi X, Wilkinson DP. A critical review of two-phase flow in gas flow channels of proton exchange membrane fuel cells. J Power Sources 2010;195:453153. doi:10.1016/j.jpowsour.2009.12.123.

[8] Santamaria AD, Cooper NJ, Becton MK, Park JW. Effect of channel length on interdigitated flowfield PEMFC performance: A computational and experimental study. Int J Hydrogen Energy 2013;38:16253-63. doi:10.1016/j.ijhydene.2013.09.081.

[9] Klages M, Enz S, Markötter H, Manke I, Kardjilov N, Scholta J. Investigations on dynamic water transport characteristics in flow field channels using neutron imaging techniques. J Power Sources 2013;239:596-603. doi:10.1016/j.jpowsour.2013.01.196.

[10] Lin R, Ren YS, Lin XW, Jiang ZH, Yang Z, Chang YT. Investigation of the internal behavior in segmented PEMFCs of different flow fields during cold start process. Energy 2017;123:367-77. doi:10.1016/j.energy.2017.01.138.

[11] Baca CM, Travis R, Bang M. Three-dimensional, single-phase, non-isothermal CFD model of a PEM fuel cell. J Power Sources 2008;178:269-81. doi:10.1016/j.jpowsour.2007.12.023.

[12] Krastev VK, Falcucci G, Jannelli E, Minutillo M, Cozzolino R. 3D CFD modeling and experimental characterization of HT PEM fuel cells at different anode gas compositions. Int J Hydrogen Energy 2014;39:21663-72. doi:10.1016/j.ijhydene.2014.09.015.

[13] Fink C, Fouquet N. Three-dimensional simulation of polymer electrolyte membrane fuel cells with experimental validation. Electrochim Acta 2011;56:10820-31. doi:10.1016/j.electacta.2011.05.041.

[14] Iranzo A, Muñoz M, Pino J, Rosa F. Update on numerical model for the performance prediction of a PEM Fuel Cell. Int J Hydrogen Energy 2011;36:9123-7. doi:10.1016/j.ijhydene.2011.04.102.

[15] Ferng Y, Su A. A three-dimensional full-cell CFD model used to investigate the effects of different flow channel designs on PEMFC performance. Int J Hydrogen Energy 2007;32:4466-76. doi:10.1016/j.ijhydene.2007.05.012.

[16] Oliveira VB, Rangel CM, Pinto AMFR. Effect of anode and cathode flow field design on the performance of a direct methanol fuel cell. Chem Eng J 2010;157:174-80. doi:10.1016/j.cej.2009.11.033.

[17] Reshetenko T V., Bender G, Bethune K, Rocheleau R. A segmented cell approach for studying the effects of serpentine flow field parameters on PEMFC current distribution. Electrochim Acta 2013;88:571-9. doi:10.1016/j.electacta.2012.10.103.

[18] Nguyen PT, Berning T, Djilali N. Computational model of a PEM fuel cell with serpentine gas 
flow channels. J Power Sources 2004;130:149-57. doi:10.1016/j.jpowsour.2003.12.027.

[19] Meyer Q, Ashton S, Torija S, Gurney C, Boillat P, Cochet M, et al. Nitrogen Blanketing and Hydrogen Starvation in Dead-Ended-Anode Polymer Electrolyte Fuel Cells Revealed by HydroElectro-Thermal Analysis. Electrochim Acta 2016;203:198-205.

doi:10.1016/j.electacta.2016.04.018.

[20] Stahl P, Biesdorf J, Boillat P, Kraft J, Friedrich K a. Water Distribution Analysis in the Outer Perimeter Region of Technical PEFC Based on Neutron Radiography. J Electrochem Soc 2015;162:F677-85. doi:10.1149/2.0351507jes.

[21] Cooper JS. Design analysis of PEMFC bipolar plates considering stack manufacturing and environment impact. J Power Sources 2004;129:152-69. doi:10.1016/j.jpowsour.2003.11.037.

[22] Carcadea E, Varlam M, Ingham DB, Patularu LG, Marinoiu A, Ion-Ebrasu D, et al. Effect of Gdl(+MPL) Compression on the PEM Fuel Cell Performance. Meet Abstr 2016;MA2016$02: 2742-2742$.

[23] Mason TJ, Millichamp J, Neville TP, El-kharouf A, Pollet BG, Brett DJL. Effect of clamping pressure on ohmic resistance and compression of gas diffusion layers for polymer electrolyte fuel cells. J Power Sources 2012;219:52-9. doi:10.1016/J.JPOWSOUR.2012.07.021.

[24] Jiang R, Mittelsteadt CK, Gittleman CS. Through-Plane Proton Transport Resistance of Membrane and Ohmic Resistance Distribution in Fuel Cells. J Electrochem Soc 2009;156:B1440. doi:10.1149/1.3240877.

[25] Nitta I, Hottinen T, Himanen O, Mikkola M. Inhomogeneous compression of PEMFC gas diffusion layer. J Power Sources 2007;171:26-36. doi:10.1016/j.jpowsour.2006.11.018.

[26] Zenyuk I V., Parkinson DY, Connolly LG, Weber AZ. Gas-diffusion-layer structural properties under compression via X-ray tomography. J Power Sources 2016;328:364-76. doi:10.1016/J.JPOWSOUR.2016.08.020.

[27] Ge J, Higier A, Liu H. Effect of gas diffusion layer compression on PEM fuel cell performance. J Power Sources 2006;159:922-7. doi:10.1016/J.JPOWSOUR.2005.11.069.

[28] Junho Je, Seungwoo Doh, Jongrok Kim MHK. Heterogeneous Porosity Distribution under Compression Condition of Gas Diffusion Layer Using Synchrotron X-Ray Tomography Junho Je. Trans E C S Soc Electrochem 2012;50:369-74.

[29] James JP, Choi H-W, Pharoah JG. X-ray computed tomography reconstruction and analysis of polymer electrolyte membrane fuel cell porous transport layers. Int J Hydrogen Energy 2012;37:18216-30. doi:10.1016/j.ijhydene.2012.08.077.

[30] Gostick JT, Fowler MW, Pritzker MD, Ioannidis MA, Behra LM. In-plane and through-plane gas permeability of carbon fiber electrode backing layers. J Power Sources 2006;162:228-38. doi:10.1016/j.jpowsour.2006.06.096.

[31] Fazeli M, Hinebaugh J, Fishman Z, Tötzke C, Lehnert W, Manke I, et al. Pore network modeling to explore the effects of compression on multiphase transport in polymer electrolyte membrane 
fuel cell gas diffusion layers. J Power Sources 2016;335:162-71.

doi:10.1016/j.jpowsour.2016.10.039.

[32] Sasmito AP, Mujumdar AS. Performance evaluation of a polymer electrolyte fuel cell with a dead-end anode: A computational fluid dynamic study. Int J Hydrogen Energy 2011;36:1091733. doi:10.1016/j.ijhydene.2011.05.171.

[33] Siegel JB, Bohac S V., Stefanopoulou AG, Yesilyurt S. Nitrogen front evolution in purged polymer electrolyte membrane fuel cell with dead-ended anode. J Electrochem Soc 2010;157:B1081. doi:10.1149/1.3425743.

[34] Meyer Q, Ashton S, Curnick O, Reisch T, Adcock P, Ronaszegi K, et al. Dead-ended anode polymer electrolyte fuel cell stack operation investigated using electrochemical impedance spectroscopy, off-gas analysis and thermal imaging. J Power Sources 2014;254:1-9. doi:10.1016/j.jpowsour.2013.11.125.

[35] Manokaran A, Pushpavanam S, Sridhar P, Pitchumani S. Experimental analysis of spatiotemporal behavior of anodic dead-end mode operated polymer electrolyte fuel cell. J Power Sources 2011;196:9931-8. doi:10.1016/j.jpowsour.2011.06.103.

[36] Siegel JB. Experiments and Modeling of PEM Fuel Cells for Dead-Ended Anode Operation 2010.

[37] Mahyari H, Hassanzadeh H, Shams M. Three dimensional transient multiphase fl ow simulation in a dead end anode polymer electrolyte fuel cell. J Mol Liq 2017;225:391-405. doi:10.1016/j.molliq.2016.11.063.

[38] Chen YS, Yang CW, Lee JY. Implementation and evaluation for anode purging of a fuel cell based on nitrogen concentration. Appl Energy 2014;113:1519-24. doi:10.1016/j.apenergy.2013.09.028.

[39] Chen J, Siegel JB, Stefanopoulou AG. Nitrogen blanketing front equilibria in dead end anode fuel cell operation. Proc 2011 Am Control Conf 2011:1524-9.

[40] Abbou S, Dillet J, Maranzana G, Didierjean S, Lottin O. Local potential evolutions during proton exchange membrane fuel cell operation with dead-ended anode - Part I: Impact of water diffusion and nitrogen crossover. J Power Sources 2017;340:337-46. doi:10.1016/j.jpowsour.2016.11.079.

[41] Meyer Q, Ronaszegi K, Robinson JB, Noorkami M, Curnick O, Ashton S, et al. Combined current and temperature mapping in an air-cooled, open-cathode polymer electrolyte fuel cell under steady-state and dynamic conditions. J Power Sources 2015;297:315-22. doi:10.1016/j.jpowsour.2015.07.069.

[42] Chen J, Siegel JB, Stefanopoulou AG, Waldecker JR. Optimization of purge cycle for dead-ended anode fuel cell operation. Int J Hydrogen Energy 2013;38:5092-105. doi:10.1016/j.ijhydene.2013.02.022.

[43] Edwards PP, Kuznetsov VL, David WIF, Brandon NP. Hydrogen and fuel cells: Towards a sustainable energy future. Energy Policy 2008;36:4356-62. doi:10.1016/j.enpol.2008.09.036. 
[44] Obeisun OA, Meyer Q, Gibbs CW, Robinson JB, Shearing PR, Bret. Advanced diagnostics applied to a self-breathing fuel cell. ECS Trans 2014;61:249-58.

[45] Yang Y, Zhang X, Guo L, Liu H. Different flow fields, operation modes and designs for proton exchange membrane fuel cells with dead-ended anode. Int J Hydrogen Energy 2018;43:176980. doi:10.1016/J.IJHYDENE.2017.10.137.

[46] Hou Y, Shen C, Yang Z, He Y. A dynamic voltage model of a fuel cell stack considering the effects of hydrogen purge operation. Renew Energy 2012;44:246-51. doi:10.1016/j.renene.2012.01.088.

[47] Siegel JB, Stefanopoulou AG. Modeling and experiments of voltage transients of polymer electrolyte membrane fuel cells with the dead-ended anode 2012;9:1-7. doi:10.1115/1.4005626.

[48] Müller EA, Kolb F, Guzzella L, Stefanopoulou AG, McKay DA. Correlating Nitrogen Accumulation With Temporal Fuel Cell Performance. J Fuel Cell Sci Technol 2010;7:021013. doi:10.1115/1.3177447.

[49] Iranzo A, Boillat P, Rosa F. Validation of a three dimensional PEM fuel cell CFD model using local liquid water distributions measured with neutron imaging. Int J Hydrogen Energy 2014;39:7089-99. doi:10.1016/j.ijhydene.2014.02.115.

[50] Meyer Q, Ashton S, Boillat P, Cochet M, Engebretsen E, Finegan DP, et al. Effect of gas diffusion layer properties on water distribution across air-cooled, open-cathode polymer electrolyte fuel cells: A combined ex-situ X-ray tomography and in-operando neutron imaging study. Electrochim Acta 2016;211:478-87. doi:10.1016/j.electacta.2016.06.068.

[51] Jung CY, Lee CS, Yi SC. Computational analysis of transport phenomena in proton exchange membrane for polymer electrolyte fuel cells. J Memb Sci 2008;309:1-6. doi:10.1016/j.memsci.2007.10.017.

[52] Kim G-S, Sui PC, Shah a. a., Djilali N. Reduced-dimensional models for straight-channel proton exchange membrane fuel cells. J Power Sources 2010;195:3240-9. doi:10.1016/j.jpowsour.2009.11.110.

[53] Chaudhary S, Sachan VK, Bhattacharya PK. Two dimensional modelling of water uptake in proton exchange membrane fuel cell. Int J Hydrogen Energy 2014;39:17802-18. doi:10.1016/j.ijhydene.2014.08.128.

[54] Watanabe K, Hamada K, Araki T. Visualization technique for time-variant hydrogen concentration distribution in porous materials using hydrogen storage alloy thin film. Int J Hydrogen Energy 2018;43:12377-85. doi:10.1016/J.IJHYDENE.2018.04.180. 